HOW

Volume 29, Number 1, pages 64 - 83

https://doi.org/10.19183/how.29.1.640

How

\title{
A Task-based Teacher Development Program in a Rural Public School in Colombia
}

\author{
Un Programa de Desarrollo Profesional Docente Basado en \\ Tareas en una Escuela Rural Pública de Colombia
}

\author{
Claudia Camila Coronado-Rodríguez ${ }^{1}$ \\ Luisa Fernanda Aguilar-Peña ${ }^{2}$ \\ María Fernanda Jaime-Osorio ${ }^{3}$ \\ Universidad Surcolombiana, Neiva, Colombia
}

\begin{abstract}
This document reports on a research study carried out in a rural public school in Colombia. The aim of the study was to identify the impact of a task-based teacher development program on three primary school teachers' teaching practices. To this effect, we used a survey, classroom observations, and semi-structured interviews before and after the implementation of the development program. We identified that teachers' perceptions, beliefs, and realities in their teaching practice influenced their performance, inside and outside the classroom. The results also showed that participants improved
\end{abstract}

She holds a B.A. in English Language and an M.A in English Language Teaching from Universidad Surcolombiana, Colombia. She is currently a full-time English Language professor at the School of Languages at Universidad Santo Tomas in Villavicencio.

clacacorodriguez@gmail.com

ORCID ID: https://orcid.org/0000-0003-2585-9383

2 She holds a B.A. in English Language from Universidad de la Amazonia, Colombia, and an M.A. in English Language Teaching from Universidad Surcolombiana, Colombia. She is currently an English teacher at San Marcos School in Acevedo, Huila.

$64 \quad$ ORCID ID: https://orcid.org/0000-0002-3156-6301

3 She is a full-time professor at Universidad Surcolombiana. She holds an M.A. in Teaching English as a Foreign Language from Universidad Internacional Iberoamericana. She is the director of the research group ILESEARCH. She is currently the chair of the EFL program at Universidad Surcolombiana in Neiva. mariafernanda.jaime@usco.edu.co ORCID ID: https://orcid.org/0000-0001-8938-8248

Received: March 10th, 2021. Accepted: October 13th, 2021.

This article is licensed under a Creative Commons Attribution-Non-Commercial-No-Derivatives 4.0 International License. License Deed can be consulted at https://creativecommons.org/licenses/by-nc-nd/4.0. 
their teaching practices regarding the processes of lesson planning and materials design. They also improved their English language performance regarding pronunciation and vocabulary use.

Keywords: primary education, teacher professional development, rural education, task-based approach

\section{Resumen}

Este documento informa sobre un estudio de investigación realizado en una escuela rural pública de Colombia. El objetivo del estudio fue el de identificar el impacto de un programa de desarrollo docente basado en tareas en las prácticas de enseñanza de tres docentes de primaria. Para lograr esto usamos una encuesta, observaciones de clase y entrevistas semiestructuradas antes y después de la implementación del programa de desarrollo. Identificamos que las percepciones y creencias de los docentes en su práctica docente influyeron en su desempeño dentro y fuera del aula. Los resultados también mostraron que los participantes mejoraron sus prácticas docentes con respecto a procesos como la preparación y diseño de materiales de la clase. También mejoraron su competencia lingüística en inglés en cuanto a la pronunciación y el uso del vocabulario.

Palabras claves: educación primaria, desarrollo profesional docente, educación rural, enfoque por tareas

\section{Introduction}

The Colombian Ministry of National Education established the General Education Law 115 in 1994; regarding L2 teaching, it aimed at "the acquisition of elements of conversation, reading, understanding, and ability to express [oneself in] at least one foreign language" (own translation). Ever since then, learning a foreign language was introduced in Colombia, and in 2004 the Ministry of National Education launched the National Program for Bilingual Education for students in primary and secondary education. This program was proposed as visionary and futuristic since it claimed that "mastering a foreign language represents a comparative advantage, an attribute of their competence and competitiveness" (Ministry of National Education, 2004). Regarding the eagerness and ambition to enter the globalized world, it focused on following the Common European Framework (CEF) which evoked a standardized learning and a mismatch in the education system.

Standardized learning is based on what the Ministry of National Education (2006) proposed in the Basic Standards of Competences in Foreign Languages: English. Its purpose is to contribute to having citizens capable of communicating in English, with internationally comparable standards (Ministry of National Education, 2006). It was also created as a key guideline for the academic community to know the communicative competences that students were expected to reach. However, for a long time, scholars have reported that students do not achieve those language proficiency levels in English. According to Instituto Colombiano para la Evaluación de la Educación (ICFES, 2018), the highest Colombian 11th graders' 
result on the English language test in 2014, 2015, and 2017 was 51 points out of 100; in 2016 and 2018 was 53 and 52, respectively. That is why Cárdenas, González, and Álvarez (2010) convey that the reality established in the CEF should have been adapted to the conditions of Colombian educational institutions, namely infrastructure, curriculum organization, use of foreign languages in the academic and cultural domains of the country, working hours, and competences of language teachers (p. 3), before adopting it as the guideline for English Language Teaching in Colombia. Sánchez and Obando (2008) also point out the gap between public and private education. For them, the first can neither comply with the high standards of education nor cope with the challenges posed by the disadvantages such as lack of resources, lesser involvement of families, overcrowded rooms, restriction in class hours and a huge diversity of students.

The problems mentioned above represent just the tip of the iceberg. Below the surface, the division of rural and urban areas deepens the gap for public education. Rural public schools have fewer resources than the ones in the urban areas causing a decline in teachers' numbers and students' enrollment, that is, fewer teachers teaching and students enrolled in formal education. In fact, the Organization for Economic Cooperation and Development (OECD henceforth, 2016) states that "Net enrolment levels vary widely across the country, from $26 \%$ in rural areas to $48 \%$ in urban ones. The current capacity of the system is insufficient to accommodate full enrolment..." (p. 10). One consequence of this insufficiency is precisely that the number of subjects and grades to be oriented relies on few teachers in the school, and that teachers assume all-subject teaching, especially in primary schools; being this a factor that may affect students' English language communicative competence development since most primary school teachers have had none or not enough training in this subject. In fact, there is a general tendency for these teachers to privilege Spanish and mathematics learning because they are perceived as the rural communities' most immediate needs.

From the previous panorama, and being two of us part of the rural public teacher community, the following research question emerged: What is the impact of a task-based teacher development program for primary teachers in a rural public school in Colombia? We wanted to involve more teachers in the path to answer this question, so we invited three primary school teachers who are not certified in ELT to enroll in an intensive teacher development program to both learn English and how to teach it.

\section{Theoretical Framework}

We based our research study on three main constructs: teaching English in rural areas, professional development, and the task-based approach. Their concepts and theoretical implications will be defined next. 


\section{Teaching English in Rural Areas}

Pérez (2001, as cited in PNUD, 2011) defines and understands rurality as a result of four components: territory (source of natural resources), population, the settlements (exchange of people, goods, and information), and the public and private institutions (provide the framework within which the entire system works) (p. 27). In the Colombian context, while DANE (2018) reported that $15.8 \%$ of the country's territory is rural, and $77.1 \%$ of the population lives in urban areas; the OECD (2016) reported that "taking density and distance into account, a little more than $30 \%$ of the population and between $60 \%$ and $76 \%$ of municipalities can be considered rural" (p. 3). There is no doubt that the remoteness of rural areas, the states of the roads, and the difficult access to them, cause deterioration in the people's quality of life (Delgado, 2014).

Regarding teaching English in a rural area, the high expectations proposed by the government and the urban-rural gap present challenges for teachers. Isolation, cultural adaptation, misconceptions that rural families have about education, motivation, infrastructure, and violence are some of them (Ramos Holguín \& Aguirre Morales, 2016). Actually, the policies proposed by the government were designed under standardization patterns and consequently, there is also a lack of coherence between what is expected and the results that can be obtained in the particularities of the rural context (Delgado, 2014; Roldán \& Peláez, 2017). In many cases, due to the lack of resources available in rural areas, teachers have come to "develop creative contextualized practices where they make the most of their localized expertise and resources available" (Cruz-Arcila, 2018, p. 66). Thus, English language teachers are responsible for adapting the contents and activities to the students' specific needs and the rural area in which they are immersed (Buitrago, 2017, p. 16), creating connections with their social reality (Cruz-Arcila, 2018), and getting closer to the inclusion of the cultural particularities of the context into the curriculum (Ramos Holguín \& Aguirre Morales, 2016). These particularities are a syllabus [curriculum] that includes the cultural particularities of rural areas, the proper introduction of teachers to the community, the participation of the community in the planning process, the access to learning resource centers, and local support.

\section{Professional Development (PD)}

Because of the rapid changes of the world, teachers need to be updated for which they need to have further teacher education and professional development. Freeman (1989) refers to PD as a "strategy of influence and indirect intervention that works on complex, integrated aspects of teaching; these aspects are idiosyncratic and individual" (p. 64). To complement this concept, Richards and Farrell (2005) state that it "serves a longer-term goal and seeks to facilitate the growth of teachers' understanding and themselves as teachers. It often involves 
Claudia Camila Coronado-Rodríguez, Luisa Fernanda Aguilar-Peña,

María Fernanda Jaime-Osorio

examining different dimensions of the teacher's practice as a basis for reflection" (p. 4). Figure 1 represents the dimensions of PD:

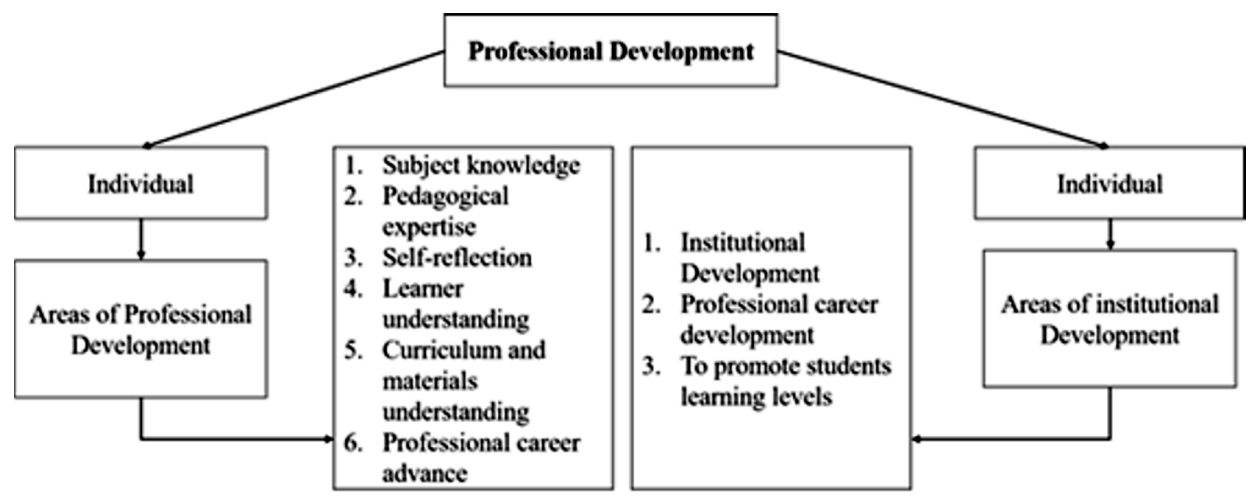

Figure 1. Professional Development Dimensions (Richards \& Farrell, 2005)

(In Figure 1 above, should be Professional career advancement. Also, students' learning levels).

The model presented in Figure 1 above has two dimensions. In the individual sphere, the professional development areas focus on the teacher, without forgetting that there are students (understanding of the learners) and an institution (understanding the curriculum). In the institutional sphere, the institution seeks to improve three domains that are outlined in the figure: the development of the institution, the teachers, and the students.

As mentioned before, rural education has proven to be a disadvantage when compared to urban education (Perfetti, 2003). The amount of population attending educational institutions, especially in remote rural areas, allows the government to invest less, which as a consequence opens up scarce initiatives to implement teacher development programs. Bonilla and Cruz-Arcila (2018) highlight this aspect asserting that rural teachers' professional growth does not follow parallel routes like those of teachers in urban areas (p. 125). It happens because of different reasons: among others, there are not enough opportunities or offers for rural teachers to participate in training courses, rural teachers do not have enough technological or economic resources, means or time for transportation to participate in the teacher development programs that are offered in the urban areas, and their needs are different from the ones in urban milieus (Bonilla-Medina \& Cruz-Arcila, 2013). PD is an essential construct for this study because through its practice, the researchers helped 
teachers to grow professionally and as a consequence we triggered the transformation of their teaching practices when teaching English.

\section{Task-Based Approach (TBA)}

The pedagogical intervention for this study was based on the Task-Based Approach (TBA). According to Buitrago Campo (2016), the TBA exposes students to develop communicative skills in the target language in the learning process, but that exposition requires the implementation of tasks (p. 97). In addition, learning revolves around the completion of meaningful tasks (Zakime, 2018; Córdoba Zuñiga, 2016; Peña \& Onatra, 2009) that are not only characterized by removing teacher-centered instruction, providing opportunities for spontaneous interaction in the foreign language, and ability to interact in real-life contexts (Willis, 1996), but by implementing/fostering activities "where the target language is used by the learner for a communicative purpose (goal) in order to achieve an outcome" (p. 23). Furthermore, tasks emphasize the how - process of doing things - and the what - the content - of Language teaching (Sánchez, 2004). Thus, TBA proposes that teachers ask learners to carry out a series of tasks where they will need to learn and recycle specific items of language (Peña \& Onatra, 2009). Willis (1996) claims that TBA consists of three phases: Pre-task, Task Cycle, and Language Focus (see Table 1 below).

Table 1. Willis' Task-Based Cycle (1996, p.38)

\begin{tabular}{|l|l|l|}
\hline \multicolumn{2}{|c|}{ Pre-task } \\
\hline Introduction to topic and tasks \\
\hline $\begin{array}{l}\text { Teacher explores the topic with the class, highlighting useful words and phrases. } \\
\text { Learners may be exposed to examples. }\end{array}$ \\
\hline \multicolumn{3}{|c|}{ Task cycle } \\
\hline \multicolumn{2}{|c|}{ Task } & \multicolumn{1}{|c|}{ Planning } \\
\hline $\begin{array}{l}\text { Students do the task in pairs or } \\
\text { small groups. Teacher monitors; } \\
\text { mistakes do not matter. }\end{array}$ & $\begin{array}{l}\text { Students prepare to report. } \\
\text { Accuracy is important, so the } \\
\text { teacher stands by and gives } \\
\text { advice. }\end{array}$ & $\begin{array}{l}\text { Students exchange or present } \\
\text { comments. Teacher listens and then }\end{array}$ \\
\hline \multicolumn{2}{|c|}{ Language Focus } \\
\hline Analysis & \multicolumn{2}{|c|}{ Practice } \\
\hline Students examine, then discuss. & Teacher conducts practice of new words. \\
\hline
\end{tabular}


Claudia Camila Coronado-Rodríguez, Luisa Fernanda Aguilar-Peña,

María Fernanda Jaime-Osorio

The table above shows that the pre-task introduces the topic to the class by providing words and phrases which are related to the topic. The task cycle encourages the holistic use of the language which favors an inductive and cognitive style to recreate natural learning conditions in the classroom. Finally, the language focus allows a closer study and assessment of the features used during the task cycle. To plan and develop the activities for the primary school teachers that were part of this study, we followed Willis' cycle since it made the researchers' planning easy and effective.

\section{Methodology}

This research study followed a qualitative approach, which focuses on “... understanding people's beliefs, experiences, attitudes, behavior, and interactions" (Pathak, Jena, \& Kalra, 2013, p. 192). We wanted to cater to our participants' needs and listen to their voices to come up with a plan that could contribute to developing their abilities to teach English as a foreign language in a rural context. Then, we aimed at planning a teacher development program to generate a real impact on the primary school teachers who were part of it. To this effect, we collected data by means of an initial interview to know our participants' perspectives on how education has changed in terms of teaching practices, how they had been teaching English, and their perceptions about professional development. We gathered data from a collaborative action research basis, which helps to improve the community in which one's practice is embedded through participatory action learning (Riel, 2019, p. 3). It also develops a four-staged spiral process (Kemmis and McTaggart, 1988; Riel, 2019).

In the first stage we, teachers and researchers, planned the activities collaboratively in accordance with the teachers' needs and the curriculum. Then, in a second stage, we acted by carrying out the plan through a six-lesson pedagogical intervention (see its description in the section below). As a third stage, we observed each of our participants while teaching three lessons. Finally, in a fourth stage, after each of the lessons had been observed, we all reflected on the teachers' practices and collected data on their own perceptions about strategies, activities, and practices that could be transformed during

70 the following lesson.

To know the effects that the teacher development program had on our participants' teaching practices, we made three initial classroom observations so we could identify their English language teaching strategies before the implementation of the program. Then, we contrasted our data with three new classroom observations per teacher and a focal group interview after the implementation. The teachers were given the opportunity to reflect on those results and share their opinions. 


\section{Pedagogical Intervention}

Considering the school curriculum and the teachers' needs and voices, we planned to pursue two objectives for the pedagogical intervention; the first was to teach the English language at a basic level; the second was to teach the English language didactics. Thus, basic functions of the language and basic vocabulary related to daily routines, colors, alphabet, school supplies, and animals in English were taught through six lessons. The pedagogical intervention took place over two years: three lessons were taught between October and November 2018, and the other three lessons between February and April 2019.

Regarding English language didactics, it was decided that the Total Physical Response (TPR) method, the storytelling approach, and the principles of collaborative work and learning by doing were the most suitable ones for primary school teachers so as to cope with the challenges posed by the context. While TPR is defined as "a language teaching method built around the coordination of speech and action, it attempts to teach language through physical activity." (Richards \& Rodgers, 2001, p. 87) Storytelling is defined as an "approach that helps students to develop language skills such as listening, imagination and predicting" (Mutiarani \& Izzah, 2015, p. 72). The principles of collaborative work and learning by doing are based on the idea that learning is a naturally social act in which the participants talk among themselves in group work (Gerlach, 1994) and that students learn from their experiences in the classroom (Kolb, 1984).

The two-hour six interventions (see Appendix A) were carefully carried out under the parameters established by Willis' (1996) task-based cycle (TBA). We considered TBA because it "enhances the creation of learning tasks that suit the needs of learners and help them master all skills successfully by providing different class exercises to complete their work" (p. 14). The participation of the teachers was focused on sharing experiences and thoughts about their strengths and weaknesses in the English language. To carry out the activities, we planned three cycles. For each cycle we planned two lessons, we put them into effect, observed how teachers developed the activities, and together reflected upon the activities.

\section{Instruments}

The techniques and instruments implemented in this project were a survey to select our participants, classroom observations before and after the pedagogical intervention, and individual and focal group semi-structured interviews.

\section{Participants}

The participants of this research study were three female primary school teachers. The oldest teacher was 55 years old, had a bachelor's degree in mathematics and 18 years of 
teaching experience. She taught all subjects to first graders. Another participant was 46 years old; she had a bachelor's degree in mathematics, 15 years of teaching experience and taught all subjects to second graders. The youngest teacher was 29 years old, had a bachelor's degree in pedagogy and five years of teaching experience. She was in charge of kindergarten. They had previously taken some English language courses, so they taught English language for one hour per week. They were given codes (T1, T2, and T3) to protect their identities. As part of the collaborative action research project, the participants were collaborators in the design of the activities for the task-based teacher development program.

\section{Data Analysis and Findings}

This section presents the data analysis procedure and the research categories. We followed six steps both simultaneously and iteratively: data collection, information preparation, data reading, data coding, text coding in themes, and description of the codes (Cresswell, 2012, p. 237). We classified the information into two categories that responded to the specific objectives of our research study: a) teaching beliefs about English teaching practices and b) transforming the teachers' attitudes toward the English class. The first category gives an overview of the relationship between the teachers' expertise in the English classes and their underlying beliefs. The second category provides a general understanding of the changes in teachers' practices, attitudes, and beliefs regarding their English language lessons after the implementation of the task-based teacher development program.

\section{Impact on Teachers' Belief System about Teaching Practices}

Throughout the years, primary school teachers' experiences shape their beliefs about teaching and their teaching practices. Malderez and Bodóczky (1999) metaphorically explain teachers' practices through the image of an iceberg: While the tip of the iceberg shows the teacher's professional behavior, the bottom shows the factors that affect it, namely, teachers' feelings, beliefs, attitudes, and values. In order to unveil their perceptions and beliefs about their own teaching practices, we asked the participants to reflect and contrast their initial and latest teaching practices. Data showed that their beliefs evolved not only throughout

72 their working years, but also as a result of their participation in the task-based development program. Experience and education are the most relevant categories that have incidence in teachers' practices transformation.

The participants perceived that their teaching practices had changed with time since those were teacher-centered in the past; they also believe that planning used to focus on fulfilling compromises with the schools and themselves. Now, they think that their teaching practices are more flexible and student-centered. For example, T3 mentioned some differences: 
"Nowadays I find more scenarios in my teaching practices; I assume a reality from another point of view. I work. with my students to offer results. Then yes, there is a great difference. It is great because I feel more at ease with my students. I used to think that I had to compromise myself [while teaching for another school] back then." [sic]

T1 perceived that teaching was complicated but with time she started focusing more on her students:

"When I was studying [(in) the undergraduate program], my teaching practices were complicated, but I acquired taste for it as I interacted more and more with my job... At the beginning I believed that education was strict and rigid, but now I feel that education is more flexible. Now, I do my best for my students to understand and learn the subject." [sic]

Complementarily, T2 said, "Yes, the undergraduate teaching practice purpose was to acquire knowledge about how to teach and then teach with those theoretical bases... I was more like a way of following a matrix, following... yes, an established schedule" [sic]. Now, she believes that teaching practices are less structured:

'But at the moment of being in the classroom, the class varies a lot and I look to follow my pupils' pace, not my own... So now I want to identify my students' needs and take knowledge to them... but also take into account their previous knowledge and what the context demands. We need to know the students' profile [where they come from and where they are going7. That is what we need the most these days". [sic]

Regarding education, the participants' beliefs changed after graduation, when they started to work. Primary school teachers thought that education consisted of learning and teaching theories, but when confronting reality, they found significant differences between theory and practice. They understand now that keeping updated with methodologies and theories for the subjects they teach is crucial. They also understand that the basis of teaching is not only beliefs but involves teachers' attitudes and values, too, and that these lie in the culture where teachers work. Part of their everyday teaching practices must be devoted to improving their teaching.

Regarding English language teaching, by means of the classroom observations we concluded that the three participants' practices were pre-communicative (Bachman, 1990), represented in the activities with a focus on isolated vocabulary learning and practice. The following are excerpts from the observations that took place before the teacher development program:

"T1 writes the numbers on the board, T1 recommends looking for the numbers the students do not know in the dictionary." (FCOR1).

"T1 writes a list of verbs in English on the board and the students have to search its translation in Spanish." (SCOR1). 
Claudia Camila Coronado-Rodríguez, Luisa Fernanda Aguilar-Peña,

María Fernanda Jaime-Osorio

"T2 starts a bowling game in which one student (leader) per group goes in front of the empty bottles and $s /$ he has to say food vocabulary correctly, s/ he watches the flashcards and pronounces the words according to each picture. If s/ he pronounces wrong, s/she does not throw the ball." (FCOR2).

"The T3 sits down and spends the last 30 minutes on her desk. She checks her cell phone." (FCOR1)

"T3 gives a guide to the students, students have to color, draw and write the parts of the face in the guide." (SCOR2)

Considering the excerpts mentioned above, the constant use of Spanish as support to teach English is evident. However, the teachers spoke in Spanish all the time, which made the English dictionary the most used tool to develop the activities since those were based on translating words that were decontextualized. It means "Translation is a change of form" (Syah, 2013, p. 3). For example, when teaching numbers, the teachers limited themselves to teaching how to write numbers in English and Spanish.

We also found that, most of the time, the students completed worksheets in class. Núñez, Téllez, and Castellanos (2013) claim that "Materials are socio-cultural resources that facilitate not only linguistic interaction but also cultural exchanges between the various human groups. Moreover, they are forms of social mediation that allow flow of knowledge" (p. 10). Nevertheless, the use of coloring guides, a dictionary, a board, and a marker did not give students much possibility to have a social mediation with the language being learned. We found that the participating primary school teachers had different attitudes, understood as "...a mental and neural state of readiness, organized through experience, exerting a directive or dynamic influence upon the individual's response to all objects and situations with which it is related" (Allport, 1935, p. 810) towards their lessons. For example, T2 used strategies such as games in her classes, and she usually involved students in the learning process. However, T1 and T3 spent their class time on word-translation coloring-guide exercises.

All in all, before the implementation of the program, the teachers perceived that their teaching practices were greatly influenced by the years of experience they had accumulated. This fact highlights that "teachers intuitively tend to make the most of their expertise, the limited resources available, and the local lingua-cultural repertoires in an attempt to help students make sense of English" (Cruz Arcila, 2018, p. 65). The teachers taught English

74 from their own experience teaching Spanish, mathematics, or biology. Although they did not have command of the English language and knew little about pedagogical strategies to teach it, the teachers, as is the case in T2, tried to use games to teach. Despite not having the necessary resources such as English language textbooks, the teacher used realia. In this way, her class was dynamic and showed that creativity develops with practice and experience. Finally, to contrast the teachers' teaching practices before the implementation of the taskbased program, T1 and T3 evidently had a structuralist language view, T2 was more empathic to teach English. 


\section{Transformation of Teaching Practices}

The transformation of the teaching practices was evident in two main aspects: (1) lesson planning and class materials design, and (2) linguistic development of vocabulary range and pronunciation patterns. We will present those results next.

\section{Lesson Planning and Class Materials Design}

After the implementation of the task-based teacher development program, we as the researchers, observed changes in the teachers' teaching practices regarding lesson planning. Not only did interviews and lesson observations give evidence of a more structured plan that mirrored the task-based approach we used in each one of the pedagogical interventions, but also showed that to plan their lessons the teachers asked for professional advice from the English language teacher at school. By acknowledging the importance of giving a purpose to the English language lessons, the teachers started planning and designing materials in collaboration with their peers to achieve their purposes. To this respect T2 and T3, expressed:

“...I am more motivated because I count on your support. Now [when] I am going to plan an English lesson and I can go to ask you how to pronounce this, or what I can do, or what else you would advise me to include... having your support, well, is more...You put more effort to better review the lessons and all that [lesson materials] ...” [sic] (T2PI)

"I think that by observing you we can also learn. For example, if I would have taught the Baby Shark song I would have played it a thousand times..., but by observing you I realized that you paused it, and repeated it, and mimicked it ... I used that song in class and it helped me to review the family members. I think you have many ideas that we can also use.” [sic] (T3PI)

During the post interview, T3 mentioned that she liked the idea of using the materials we shared with them during the interventions and $\mathrm{T} 2$ showed preference towards adapting them:

"[I would like to have] all the materials we worked on... For example, the poem about the colors." (T3PI)

"...We could have done the tale in Spanish and where there was a color, we could paste the color... such color, and we could say the poem and there they could stop, for example, to say blue or red, or sticker color." [sic] (T2PI)

Moreover, post-observation excerpts support these findings. From the first observation, we reported the following: 
Claudia Camila Coronado-Rodríguez, Luisa Fernanda Aguilar-Peña,

María Fernanda Jaime-Osorio

"T2 starts showing the students some pictures and gives away candies for students to eat; she pastes the images around the classroom and repeats the name of the candy and the color. Then the teacher explains the game rules they will play next." (SCOR2)

"T2 associates the pronunciation of some words in English with a movement." (SCOR2)

"T3 gives photocopies to the students for them to write the body parts they have learned in class; then, she reproduces a video to complement students' activity.” (FCOR2)

"T3 says they are going to listen to a song because they know the family members." (SCOR2)

The teachers started to leave behind their translation activities and the dictionary as the main class resources; instead, flashcards, videos, and songs started to become incorporated into their lesson plans. This gives evidence of a shift in their perceptions of language teaching. All the same, they began to elaborate the English lessons in a more detailed and creative way. They put aside pre-communication activities (Bachman, 1990) and began to create activities that had been taught in the task-based teacher development program. Therefore, the program had a positive impact since it allowed the teachers to explore different pedagogical strategies to teach the foreign language.

\section{Linguistic Advancement of Teachers}

The participating primary-school teachers had linguistics advancement through the task-based teacher development program. Changes in this area can be demonstrated by contrasting the teachers' language use before and after the implementation of the program.

Before the implementation of the program, the teachers expressed the great need that they had regarding pronunciation. In relation to this, T3 expressed: "It is very difficult for me to pronounce English." 'T2 also espoused pronunciation as the aspect with more relevance to be learned since "the most important is the pronunciation because sometimes you are too focused on theory, on the structure, all this about writing, but not on the pronunciation." This participant also claimed having no preparation in pronunciation: "I just pronounce the word my best. I pronounce it in a way or another, but I do not know if my pronunciation is accurate."

Pronunciation is understood as "the production of sounds that we use to make meaning" (Yates, 2002, p. 1). The way the teachers usually mispronounced words in English was evident in the classroom observations. For instance, in the third classroom observation, T1 instead of pronouncing ['snerk], the students pronounced [snac] for the word snake. In the first classroom observation, T1 pronounces the word shoes, as it is read in Spanish /'shoes/. Being one of the teachers' priorities to improve their pronunciation, we included basic aspects of pronunciation in the task-based development program. After this pedagogical intervention, the participants improved two aspects: phonological and phonetic awareness. 
As is related on line 12 from the observation 1 that we carried out to T3: "She tries to have a more accurate pronunciation." We noted this on that day since the class was about parts of the body and T3 made an effort to pronounce the vocabulary of that lesson. Postobservations are marked with the effort of the teachers to pronounce the words accurately, especially when teaching new vocabulary to students; besides, the use of English as a means of instruction (giving commands and instructions, asking and answering short questions) was more prominent after the intervention process. The following are excerpts from the initial observations:

"T1 speaks all the time in Spanish." (FCOR1)

"T2 ask the students; 'what do you eat for breakfast?' in Spanish." (FCOR1)

In contrast, the following are excerpts from the post-observations:

"T3 mentions parts of the face in English." (FCOR1)

"From her desk, T3 calls students one by one and practice [s] pronunciation with them." (FCOR1) [sic]

At the end of the task-based teacher development program, the teachers achieved linguistics advancement in terms of pronunciation and vocabulary and basic functions of the language such as commanding, asking and answering questions, and paraphrasing explanations briefly. That shows the beginning of a new change in their teaching practices and a new way of gaining self-confidence when teaching English.

\section{Conclusions}

This study focused on how the implementation of a task-based teacher development program influences the teaching practices of three rural primary school teachers from a public school in Colombia. In line with Richards and Rodgers (2001), we believe that TBA "enhances the creation of learning tasks that suit the needs of learners and help[s] them master all skills successfully by providing different class exercises to complete their work" (p. 14). Although the participants did not develop linguistic skills to a high proficiency level, their pedagogical practices when teaching English moved from focusing on grammar and vocabulary translation to a more functional, student-centered practice.

Collaborative action research and the task-based program allowed the participants to learn from themselves and learn from each other to benefit their students' learning processes, responding to their institutional and students' immediate needs. Even though rural primary school teachers had different perceptions regarding their experiences in education and English language teaching, they became aware of the importance of aspects such as lesson planning, materials design, and the approaches to teach the language. Not only did they 
become aware, but they also proved that theory can and should be taken into practice in the language classroom; showing the gap between theory and practice can be reduced through constant practice. An evident consequence of the teachers' changes in beliefs, paradigms, and practices, is that their students became directly and positively influenced by these new ways of approaching foreign language learning.

We also want to highlight that despite "the use of L1... a common occurrence in foreign language teaching contexts... [that] often receives criticism for its interference with the target language acquisition" (Pan, 2010, p. 87), we see the use of the L1 as a positive aspect in the target language learning; in fact, the use of the target language in the classroom corresponds to an important achievement in our research study. It is a change in the teachers' attitudes and practices that allowed them to develop more active and interesting lessons for their students. We recognize that among the limitations of the proposed task-based teacher development program is the fact that the linguistic skills of the teachers were not fully developed to the level of competence that a basic user of the language should hold; to achieve that purpose, longer periods of intervention and tutoring should take place.

All in all, based on the pieces of evidence of this study, we want to insist on a general call to the Ministry of National Education for the implementation of PD programs in the rural areas of Colombia since they are key and the accessible means to provoke significant changes in English language teaching-learning-assessing processes. Those programs give teachers opportunities to work collaboratively to build and share their knowledge of this discipline, for which it is necessary for them to be in constant monitoring. It is not enough to give isolated training activities to achieve a real improvement in English language teaching classes; teachers involved in these kinds of programs should be willing to provide constant feedback so that the program can have/cause a major impact in the long run.

\section{References}

Allport, G. (1935). Attitudes. In C. Murchison (Ed.), Handbook of social psychology (pp. 798-844). Clark University Press.

Bachman, L. F. (1990). Fundamental considerations in language testing. Oxford University Press.

Bonilla-Medina S., \& Cruz-Arcila, F. (2013). Sociocultural factors involved in the teaching of English as foreign language in rural areas of Colombia: an analysis of the impact on teachers' professional development. Research in Teacher Education, 3(2), 28-33.

Bonilla, S., \& Cruz-Arcila, F. (2014). Critical Socio-Cultural Elements of the Intercultural Endeavour of English Teaching in Colombian Rural Areas. Profile: Issues in Teachers' Professional Development, 16, 117-133. https://doi.org/10.15446/profile.v16n2.40423 
Buitrago Campo, A. C. (2016). Improving 10th graders' English communicative competence through the implementation of the task-based learning approach. Profile: Issues in Teachers' Professional Development, 18(2), 95-110. http://dx.doi.org/10.15446/profile.v18n2.48272

Buitrago, L. (2017). El inglés en la zona rural de Colombia: aplicación del modelo Working with people, del método Content-based y de los ambientes de aprendizaje en la clase de lengua extranjera en Subia, Cundinamarca. [Bachelor dissertation, Pontifical Xavierian University] PXU Campus Repository. https://repository.javeriana.edu.co/handle/10554/35431

Cárdenas, M., González, A., \& Álvarez, J. (2010). El desarrollo profesional de los docentes de inglés en ejercicio: algunas consideraciones conceptuales para Colombia. Folios, 31, 49-67. https://doi.org/10.17227/01234870.31 folios49.67

Córdoba Zúñiga, E. (2016). Implementing task-based language teaching to integrate language skills in an EFL program at a Colombian university. Profile: Issues in Teachers' Professional Development, 18(2), 13-27. http://dx.doi.org/10.15446/profile.v18n2.49754

Creswell, J. W. (2012). Educational Research: Planning, conducting, and evaluating quantitative and qualitative research ( $4^{\text {th }}$ ed.). Pearson.

Cruz Arcila, F. (2018). The wisdom of teachers' personal theories: Creative ELT practices from Colombian rural schools. Profile: Issues in Teachers' Professional Development, 20(2), 65-78. https:/ / doi.org/10.15446/profile.v20n2.67142

Delgado, M. (2014). La educación básica y media en Colombia: retos en equidad y calidad. Bogotá, Colombia. Centro de Investigación económica y social. Research study. [Primary and Secondary Education in Colombia, challenges of equality and quality. Bogotá, Colombia. Center of economic and social research, 2014.]

Freeman, D. (1989). Teacher training, development, and decision making: A model of teaching and related strategies for language teacher education. TESOL Quarterly, 23(1), 27. https:// doi.org/10.2307/3587506

Gerlach, J. M. (1994). “Is this collaboration?” In K. Bosworth \& S. J. Hamilton (Eds.), Collaborative Learning: Underlying Processes and Effective Techniques, New Directions for Teaching and Learning. No. 59.

Instituto Colombiano para la Evaluación de la Educación (ICFES). (2018). National report of the examination of results Saber $11^{\circ}$ [PDF file]. https://www.icfes.gov.co/documents/20143/1711757/ Informe $\% 20$ nacional $\% 20$ resultados $\% 20$ examen $\% 20$ saber $\% 2011-\% 202018$.pdf

Kemmis, S., \& McTaggart, R. (1988). Action research model. Retrieved from https://www.scribd. com/doc/232329702/Action-Research-Model-by-Kemmis-and-Mctaggart

Kolb, D. (1984). Experiential learning: Experience as the source of learning and development. Prentice Hall.

Malderez, A., \& Bodóczky, C. (1999). Mentor courses: A resource book for trainer-trainers. Cambridge University Press

Ministry of National Education. (1994). Ley General de Educación. Colombia. https://www.mineducacion.gov.co/1621/articles-85906_archivo_pdf.pdf 
Claudia Camila Coronado-Rodríguez, Luisa Fernanda Aguilar-Peña,

María Fernanda Jaime-Osorio

Ministry of National Education. (2004). National Program of Bilingual Education. Colombia. https:// www.mineducacion.gov.co/1621/articles-132560_recurso_pdf_programa_nacional_bilinguismo.pdf

Ministry of National Education. (2006). Basic Standards of Competences in Foreign Languages: English. https://aprende.colombiaaprende.edu.co/sites/default/files/naspublic/Anexo $\% 2015 \% 20$ Pedagogical\%20Principles\%20and\%20Guidelines.pdf

Mutiarani, M., \& Izzah, L. (2015). The power of storytelling in teaching English to young learners. Universitas Muhammadiyah Jakarta. pp. 70-81. https://doi.org/10.13140/RG.2.2.12171.03362

National Administrative Department of Statistics (DANE). (2018). Distribución de población por ubicación. https://www.dane.gov.co/index.php/estadisticas-por-tema/demografia-y-poblacion/ censo-nacional-de-poblacion-y-vivenda-2018/donde-estamos

Núñez, A., Téllez, M. F., \& Castellanos, J. (2013). Proposal for the research line materials development and didactics ascribed to the research group: Critical pedagogy and didactics for social transformation [Unpublished manuscript, School of Education]. Universidad Externado de Colombia, Bogotá, Colombia

Organization for Economic Cooperation and Development (OECD). (2016). Education in Colombia [PDF file]. http://www.oecd.org/education/school/Education-in-Colombia-Highlights.pdf

Pathak, V., Jena, B., \& Kalra, S. (2013). Qualitative research. https://www.ncbi.nlm.nih.gov/pmc/ articles/PMC3757586/

Pan, Y. (2010). The use of L1 in the foreign language classroom. Colombian Applied Linguistics, 12(2), 87-96.

Peña, M., \& Onatra, A. (2009). Promoting oral production through the task-based learning approach: A study in a public secondary school in Colombia. Profile: Issues in Teachers' Professional Development, 11(2), 11-26.

Perfetti, M. (2003). Estudio sobre la educación para la población rural en Colombia. In Food and Agriculture Organization, Educación para la población Rural en Brasil, Chile, Colombia, Honduras, México, Paraguay y Perú. (pp. 164-216). FAO.

Pérez, E. (2001). Hacia una nueva visión de lo rural. In N. Giarracca (Comp.), Una nueva ruralidad en América Latina en Programa de las Naciones Unidas para el Desarrollo (PNUD). Colombia rural. Razones para la esperanza. Informe Nacional de Desarrollo Humano. Bogotá.

Ramos Holguín, B., \& Aguirre Morales, J. (2016). English language teaching in rural areas: A new challenge for English language teachers in Colombia. Cuadernos de Lingüistica Hispánica, 27, 209-222.

Richards, J. C., \& Farrell, T. S. (2005). Professional development for language teachers (1 ${ }^{\text {st }}$ ed.). Cambridge University Press.

Richards, J. C., \& Rodgers, T. S. (2001). Approaches and methods in language teaching. Cambridge University Press. https://doi.org/10.1017/CBO9780511667305 
Riel, M. (2019). Understanding collaborative action research. https://base.socioeco.org/docs/center_ for_collaborative_action_research.pdf

Roldán, A. M., \& Peláez, Ó. (2017). Pertinencia de las políticas de enseñanza del inglés en una zona rural de Colombia: un estudio de caso en Antioquia. Íkala. Revista de Lenguaje y Cultura, 22(1), 121-139.

Sánchez, A. (2004). The task-based approach in language teaching. International Journal of English Studies IJES, 4, 39-71. University of Murcia. https://doi.org/10.6018/ijes.4.1.48051

Sánchez, A. C., \& Obando, G. V. (2008). Is Colombia Ready for "Bilingualism”?. Profile: Issues in Teachers' Professional Development, 9(1), 181-195.

Syah, R. (2013). Translation techniques used in lazy daze in the very best of Donald duck comics 7th bilingual edition [Unpublished B. Ed. degree dissertation]. Faculty of Humanities, Dian Nuswantoro University. https://core.ac.uk/download/pdf/35373824.pdf

Willis, J. (1996). A framework for task-based learning. Pearson P T R.

Yates, L. (2002). Fact sheet - What is pronunciation? Adult Migrant Program Research Centre. La Trobe University. (pp. 1-8) http://www.ameprc.mq.edu.au/docs/fact_ sheets/01Pronunciation.pdf

Zakime, A. (2018). What is task-based learning? [webpage] https://www.whatiselt.com/singlepost/2018/01/19/What-is-Task-based-learning 


\section{Appendix A. Interventions}

\begin{tabular}{|c|c|}
\hline Intervention No. 1 & Topic: Pronunciation \\
\hline \multicolumn{2}{|c|}{ Objective: Use the correct pronunciation of vowels. } \\
\hline \multicolumn{2}{|c|}{ Task Cycle } \\
\hline \multicolumn{2}{|c|}{$\begin{array}{l}\text { Pre-Task: R3 taught the pronunciation of vowels and then showed flashcards } \\
\text { with vocabulary related to the poem "Mrs. Moon" by Roger McGough. } \\
\text { Task: Teachers read the poem with R3's help } \\
\text { Planning: Teachers prepare a report about their insights about the poem. } \\
\text { Report: Teachers reported their insights about the poem. } \\
\text { Language focus: Teachers and R2 analyzed the activity. }\end{array}$} \\
\hline \multicolumn{2}{|c|}{ Resources } \\
\hline \multicolumn{2}{|c|}{ T.V., flashcards, markers, laptop, white sheet of paper, pens, pencils, HDMI cable. } \\
\hline Intervention No. 2 & Topic: School Supplies \\
\hline \multicolumn{2}{|c|}{ Objective: Identify and use vocabulary related to school supplies and colors. } \\
\hline \multicolumn{2}{|c|}{ Task Cycle } \\
\hline \multicolumn{2}{|c|}{$\begin{array}{l}\text { Pre-task: R2 taught some vocabulary about school supplies and colors. Also, } \\
\text { she taught how to build simple sentences such as: The sharpener is blue. } \\
\text { Task: Teaches read a conversation in which the school supplies vocabulary is contextualized. } \\
\text { Planning: Teachers made a conversation following an example given by R2. } \\
\text { Report: Teachers read and act out their conversations. } \\
\text { Language focus: Teachers and R2 analyzed the activity. }\end{array}$} \\
\hline \multicolumn{2}{|c|}{ Resources } \\
\hline \multicolumn{2}{|c|}{ T.V., flashcards, markers, laptop, white sheet of paper, pens, pencils, HDMI cable. } \\
\hline Intervention No. 3 & Topic: Daily Routines \\
\hline \multicolumn{2}{|l|}{ Objective: Report daily routines. } \\
\hline \multicolumn{2}{|c|}{ Task Cycle } \\
\hline \multicolumn{2}{|c|}{$\begin{array}{l}\text { Pre-task: R2 taught vocabulary related to the daily routines and created } \\
\text { sentences about daily routines based on teachers' daily routines. } \\
\text { Task: The teachers practiced daily routines pronunciation and R2 presented an example. } \\
\text { Planning: The teachers wrote their daily routines from Monday to Sunday. } \\
\text { Report: The teachers reported their daily routines orally. } \\
\text { Language focus: Teachers and R2 analyzed the activity. }\end{array}$} \\
\hline
\end{tabular}




\begin{tabular}{|c|c|}
\hline \multicolumn{2}{|c|}{ Resources } \\
\hline \multicolumn{2}{|l|}{ T.V., flashcards, laptop, HDMI cable. } \\
\hline Intervention No. 4 & Topic: Living in the countryside \\
\hline \multicolumn{2}{|l|}{ Objective: Describe a farm animal. } \\
\hline \multicolumn{2}{|c|}{ Task Cycle } \\
\hline \multicolumn{2}{|c|}{$\begin{array}{l}\text { Pre-task: R2 taught vocabulary related to farm animals (nouns and adjectives). } \\
\text { Then, she built and wrote short sentences to describe animals. } \\
\text { Task: The teachers chose one animal they liked. } \\
\text { Planning: The teachers created a puppet of the chosen animal and wrote a description of it. } \\
\text { Report: The teachers read the description and showed their puppet. } \\
\text { Language focus: The teachers analyzed the activity. }\end{array}$} \\
\hline \multicolumn{2}{|c|}{ Resources } \\
\hline \multicolumn{2}{|c|}{ Paper bags, colors, a pair of scissors, glue, flashcards, laptop, T.V., HDMI cable. } \\
\hline Intervention No. 5 & Topic: Stories \\
\hline \multicolumn{2}{|l|}{ Objective: Tell stories. } \\
\hline \multicolumn{2}{|c|}{ Task Cycle } \\
\hline \multicolumn{2}{|c|}{$\begin{array}{l}\text { Pre-task: R2 presented and taught the vocabulary from the tale "The farmer and the Beet." } \\
\text { Task: R2 read the tale "The farmer and the Beet" with good intonation and pronunciation. } \\
\text { Planning: The teachers prepared themselves to retell the tale. } \\
\text { Report: The teachers retold the tale. } \\
\text { Language focus: The teachers analyzed the activity. }\end{array}$} \\
\hline \multicolumn{2}{|c|}{ Resources } \\
\hline \multicolumn{2}{|c|}{ Flashcards, tale "The Farmer and the Beet", laptop, T.V., HDMI cable. } \\
\hline Intervention No. 6 & Topic: Lesson Planning \\
\hline \multicolumn{2}{|c|}{$\begin{array}{l}\text { Objective: Identify the parts of the lesson planning (pre, while, post). } \\
\text { Plan a two-hour lesson to be implemented and observed by R2. }\end{array}$} \\
\hline \multicolumn{2}{|c|}{$\begin{array}{l}\text { Task Cycle } \\
\end{array}$} \\
\hline \multicolumn{2}{|c|}{$\begin{array}{l}\text { Pre-task: R2 taught how to plan a lesson. } \\
\text { Task: The teachers chose a topic of their preference. } \\
\text { Planning: With the topic in mind, a two-hour lesson was } \\
\text { planned. They followed the steps given by the R2. } \\
\text { Report: The teachers shared their ideas and gave feedback to each other. } \\
\text { Language focus: The teachers planned and carried out a lesson, which was then observed by R2. }\end{array}$} \\
\hline \multicolumn{2}{|c|}{ Resources } \\
\hline
\end{tabular}

